\title{
Conservation by Design
}

\section{MEREDITH ROOT-BERNSTEIN* $†$ AND RICHARD J. LADLE††}

*Department of Ecology, Pontificia Universidad Católica de Chile, Santiago, Chile, email mrootbernstein@bio.puc.cl †School of Geography and the Environment, Oxford University, South Parks Road, Oxford OX1 3PS, United Kingdom $\ddagger$ Department of Agricultural and Environmental Engineering, Universidade Federal de Viçosa, Viçosa, Brazil

\begin{abstract}
Conservation researchers are increasingly aware of the need to conduct interdisciplinary research and to engage nonscientists in practical applications of conservation biology. But so far, industrial designers have been left out of such collaboration and outreach efforts. Conservation of wildife often depends on products such as nest boxes, feeders, barriers, and corridors, all of which have a designed component that is frequently overlooked. Furthermore, many products are adopted without testing on short or long time scales. We argue that the design of products for conservation, and bence their functionality, effectiveness, and value, can be improved through collaboration with industrial designers. We see four key benefits that can arise from interactions with industrial designers: improvement of product quality and value, innovation and improvement in functionality of products, harmonization of conservation products with local values, and development of a psychological biomimesis approach to design. The role of industrial designers in conservation projects would be to improve factors such as product durability, affordability, functionality, and aesthetic appeal to local people. Designers can also belp to create multiple product options whose success can be tested in the field. We propose that collaborations with industrial designers can contribute to the development of improvements to existing products and innovations in the practice of animal conservation.
\end{abstract}

Keywords: barrier, corridor, design, interdisciplinary, nest box

Conservación Por Diseño

Resumen: Los investigadores de conservación están cada vez más conscientes de la necesidad de realizar investigaciones interdisciplinarias e involucrar a no científicos en las aplicaciones prácticas de la biología de la conservación. Pero hasta abora, los diseñadores industriales han sido dejados fuera de estos esfuerzos de colaboración y extensión. La conservación de vida silvestre depende de productos como cajas de anidación, comederos, barreras y corredores, que tienen un componente diseñado que a menudo es pasado por alto. Más aun, muchos productos son adoptados sin ser probados en escalas de tiempo cortas o largas. Argumentamos que el diseño de productos para la conservación, y por lo tanto su funcionalidad, efectividady valor, puede ser mejorado mediante la colaboración con diseñadores industriales. Vemos cuatro beneficios clave que puede derivarse de interacciones con diseñadores industriales: mejoramiento de la calidad y valor del producto, innovación y mejoramiento de la funcionalidad de los productos, armonización de los productos de conservación con los valores locales y desarrollo de un enfoque de biomimesis psicológica en el diseño. El papel de diseñadores industriales en proyectos de conservación sería para mejorar factores como la durabilidad, asequibilidad, funcionalidad y atracción estética de los productos. Los diseñadores también pueden ayudar a crear múltiples opciones para los productos cuyo éxito puede ser probado en el campo. Proponemos que las colaboraciones con diseñadores industriales pueden contribuir al desarrollo de mejoras a los productos existentes así como innovaciones en la práctica de la conservación de animales.

Palabras Clave: barrera, caja de anidación, corredor, diseño, interdisciplinario 


\section{Introduction}

There is a broad consensus among conservationists that finding solutions to the global biodiversity crisis will require considerable innovation combined with genuinely multidisciplinarity and publicly engaged approaches (Noss 1997; Chan 2008). Conservation biology needs to reach out to a much broader community of academics and practitioners in fields as diverse as anthropology, history, political geography, and environmental psychology (Brosius 2006; Ladle \& Jepson 2008). One promising but underutilized group of individuals, who possess skills that are potentially useful to conservation, are designers and builders of products and infrastructures, such as engineers and industrial designers.

There has been little recognition in conservation biology of the benefits that could be derived from collaboration with industrial designers. This lack of interest is probably mutual because, at first view, nature conservation seems to have little to offer a profession that seems to be associated primarily with the urban environment. Nevertheless, this view neglects the design of equipment and products for wildlife conservation, a ubiquitous feature of nearly all conservation interventions. Moreover, as the focus of conservation inevitably shifts toward the redesign of anthropogenic habitats (Rosenzweig 2003), there will be an increasing need for individuals who can devise innovative solutions that allow species to thrive in human-dominated habitats. We argue that more attention needs to be paid to conservation design and that collaborations with industrial designers are likely to improve the design process and performance of products for conservation and have long-term benefits for conservation.

\section{Industrial Design}

Industrial design is the design of products for manufacture in mass quantities, limited editions, or as one-off conceptual items (Fiell \& Fiell 2003, 2006). Industrial design includes the design of products as different as vacuum cleaners, space shuttles, tea pots, and telephone booths and differs from engineering in its attention to aesthetic considerations, although many engineered products have designed components or aspects (Fiell \& Fiell 2006).

One of the benefits of novel and original designs is their potential to generate new and desirable interactions among product, user, and environment. For example, "[d]esign practice should respond... to technical, functional and cultural needs and go on to create innovative solutions which communicate meaning and emotion and which ideally transcend their appropriate form, structure and manufacture" (Fiell \& Fiell 2003:17). Some designers hope to move beyond the creation of objects to the design of "responsive" environments that take part in a "dialogue" between users, methods of production, and existing products (Fiell \& Fiell 2003). The idea of an "ecology of products" connecting the human experience to its surroundings also extends to increased concern about environmental responsibility during production (Fiell \& Fiell 2003). Thus, the goal of industrial design is not simply to produce functional products or even aesthetically pleasing functional objects, but also to participate in the making of new ways of living, thinking, and feeling.

Although the majority of products are designed for the average user, there are also strands of industrial design that concentrate on the design of products for groups with particular needs, such as children (Fiell \& Fiell 2003; Markopolous \& Bekker 2003; Read \& MacFarlane 2006), the elderly (Fiell \& Fiell 2003; Forlizzi et al. 2004; Baskinger 2007), and patients in hospital (e.g., Karlin \& Zeiss 2006). Design in these areas focuses on issues such as assessing the preferences of users, considering their particular movement and perceptual abilities, reducing complexity of use, and embedding products in a narrative of positive meanings. Designing for use with animals could be viewed as an extension of the design of products for groups of users with specific needs.

\section{Approaches to Conservation Design}

Conservation products, as we call them here, are objects used to interact with or control animals or to influence the interactions of animals with their environment. We did not consider plant conservation. Ex situ conservation techniques, including helping animals to breed and rear young and teaching captive-reared animals how to survive when released into the wild (Griffen et al. 2000; Stamps \& Swaisgood 2007), use a variety of conservation products, for example, cages, enrichment objects, model parents, and model predators. The design of effective ex situ wildlife conservation products calls for a conservation-behavior approach (Buchholz 2007). In a conservation-behavior approach principles of animal behavior or knowledge of the behavior of given species are applied to the design of conservation programs (Buchholz 2007). For example, successful training of an animal to avoid its natural predators requires pairing a predator model displaying the necessary cues (and no salient unnatural cues) with an aversive stimulus that elicits the most adaptive response and not some other response (Griffen et al. 2000). Limitations of stimulus-response pairs are well known in psychology and need to be taken into account when designing training regimes and apparatus (Hollis 1997). For example, an electric shock might cause the animal being trained to freeze, which would be maladaptive training if it is more likely to survive by fleeing (Griffen et al. 2000). The design of training equipment and the social and environmental enrichment of captivereared animals have generally received less attention in the conservation literature than in other areas, such as the study of the welfare of laboratory and farm animals 
(e.g., Barnett 2007; Jensen \& Pedersen 2007; Nicol et al. 2008).

In situ techniques of wildlife conservation, like ex situ techniques, are often site-specific solutions derived from informal knowledge. This knowledge may be built up through an iterative process of adaptive management (Venter et al. 2008). Habitat creation and management is a primary tool in in situ wildlife conservation. This can take the form of habitat modification through the use of heavy equipment, or, more recently, the use of strategically chosen species, such as megaherbivores, to naturally modify the environment (e.g., Vera 2000). Agrienvironment schemes try to provide habitat for targeted species in field borders and hedgerows on agricultural lands (Wade et al. 2008). More generally, habitat improvement is a major purpose of many smaller conservation areas that carefully manage their habitats to meet certain biodiversity targets (e.g., to achieve y breeding pairs by time $\mathrm{x}$ ). Although agrienvironment schemes and the use of megaherbivores are examples of habitat enhancement at the landscape scale, habitat enhancement may also include complementary or stand-alone small-scale design elements. For example, nest boxes are a common tool for providing additional nesting spaces (Katzner et al. 2005; Bolton et al. 2004; Piper et al. 2002). Animal feeders are often used for reasons other than conservation, but in some cases they are used to selectively benefit threatened species, such as red squirrels (Sciurus vulgaris) in Britain (Bertram \& Moltu 1986; Gurnell \& Pepper 1993; Shuttleworth 1999).

Another area of conservation with clear design elements is the creation of wildlife barriers to keep out invasive species (e.g., Day \& MacGibbon 2002) or to keep wild predators and pest animals away from livestock or people (Breitenmoser et al. 2005; Osborn \& Hill 2005). These barriers can be physical or psychological, as when the sound of bees is used to scare away elephants (Loxodonta africana) (King et al. 2007) or when models of owls are used as wildlife "scarecrows" (Osborn \& Hill 2005). We were unable to find examples of products that have been designed to make an inhabitable habitat more attractive psychologically to targeted wildlife so that they choose not to leave it. Acclimatizing translocated or captive-reared animals to their new habitat either before release or during captivity is one way of manipulating the psychological impact of a habitat (Swaisgood \& Stamps 2007). Animals raised in captivity tend to seek features in the wild that are similar to those in captivity, whether those features are natural or not (Swaisgood \& Stamps 2007).

Corridors connecting fragments of habitats are another important tool in in situ conservation (Hilty et al. 2006). Corridors allow animals to disperse, migrate, and find habitat suitable for all of their life stages and needs (e.g., Bolger et al. 2001; Chetkiewicz et al. 2006; Davies \& Pullin 2007) and could help animals track suitable envi- ronments during climate change (Stewart \& Lister 2001). Important factors in corridor design include spatial scale of the corridor, movement patterns and habitat uses of target species, and possible changes in the frequency of social interactions within species, between predators and prey, between competitor species, and with humans as a result of animals using narrow strips or small patches of habitat (Hilty et al. 2006). Local- and regional-scale corridors include greenbelts, riparian buffer zones, mountain ridges, and stepping-stones composed of protected areas, whereas small-scale corridors include road overpasses and underpasses consisting of tunnels sunk under roads (Hilty et al. 2006).

There are many other examples of design of products or structures used by animals, such as urban planning, reserve design, zoo design, and design for domestic and laboratory animals. These topics are outside the scope of this essay, but they illustrate the plethora of opportunities and challenges potentially available to designers working in the areas of conservationist.

\section{Effectiveness of Existing Conservation Design}

Testing the efficacy of in situ techniques has been inconsistent. For example, although there has been thorough testing of some barriers (Day \& MacGibbon 2002), there has been little analysis of the efficacy of corridors (Woodroffe et al. 2005; Hilty et al. 2006; Davies \& Pullin 2007). Fish passes for small endangered fish species in an area of Belgium were only tested for their efficacy 12 years after their installation (Knaepkens et al. 2007). Moreover, products sometimes turn out to be only partially effective when they are eventually tested. Pingers (audio alarms), which are now required in many countries to reduce the bycatch of large marine mammals, proved ineffective in scaring away dugong (Dugong dugon), a primary target of the technology in Australia (Hodgson et al. 2007). In Banff National Park, small murid species, unlike other mammals, have a higher success rate of crossing narrow rather than wide overpasses, and they prefer crossings with dense cover (McDonald \& Cassady St. Clair 2004). Although in some cases extensive planning and data collection go into the process of conservation design (Hilty et al. 2006), many in situ conservation products are tested only after being widely deployed. Moreover, many of the results of apparatus testing are only in the gray literature. This contributes to the slow progress in developing effective conservation products.

Despite the shortfalls of the practice of conservation design, in some cases human-modified habitats are very successful. Endangered iguanas (Cyclura lewisi) on Gran Cayman island prefer artificial nests and retreats to natural ones (Goodman et al. 2005). Translocated rabbits (Oryctolagus cuniculus) in Spain respond to habitat modifications, including provisioning and artificial 
warrens manufactured from plastic or constructed from wood (Cabezas \& Moreno 2007). Loons (Gavia immer) in Wisconsin used $50 \%$ of available artificial nesting platforms and had higher reproductive success when using the platforms (Piper et al. 2002). Nest boxes increase reproductive success in some bird species (e.g., Bolton et al. 2004; Katzner et al. 2005). The results of a study of culverts and over- and underpasses along a highway in Spain showed that all types of corridors are used by nearly all species in the area and that these structures represent a good investment (Mata et al. 2008).

Even where short-term success in conservation design is evident, the long-term population-level effects of most products for animal conservation have yet to be proven. Several decades of research on providing British red squirrels with artificial nests and feeders that exclude invasive grey squirrels has not yet resulted in appreciable population increases or spread of red squirrels (Bertram \& Moltu 1986; Gurnell \& Pepper 1993; Shuttleworth 1999). Unlike research on animal welfare in laboratories and farms (e.g., Dawkins 2006), conservation studies rarely give animals multiple options for what kind of habitat modification they prefer. In an exception to this trend, researchers found that House Wrens (Troglodytes aedon) do not prefer to nest in cleaned nest boxes as had been presumed, but nest with equal frequency in nest boxes with and without old nests in them (Thompson \& Neill 1991). It is possible that both successes and failures in the design of modified habitats for in situ conservation could be improved by simply allowing animals to choose different designs or options, although animal preferences in the short term may not correspond to designs that benefit them in the long term. Long-term controlled studies are therefore also needed to distinguish effective from ineffective designs.

\section{When to Work with Industrial Designers}

Collaborating with industrial designers could be valuable whenever ecological data or recommendations have to be converted into objects with the goal of influencing species' interactions with their environment. Landscapescale, site-specific elements of conservation design, such as riparian corridors, will be less appropriate for collaboration with industrial designers and more appropriate for landscape designers. Products used in high quantities or that could be designed to be easily adapted to sitespecific or species-specific needs, such as nest boxes and feeders, will be more appropriate for collaboration with industrial designers. The same is true for ex situ conservation, where landscape designers may design large enclosures, for example in zoos, but industrial designers would be more appropriate for the design of enrichment objects (objects that provide mental stimulation) used in cages. Many conservation projects will include a mix of elements best designed by different types of designers.
Conservation design can provide technical solutions to ecological problems by aligning itself with a behavioral approach to conservation. This approach uses animal behavior as the basis for addressing issues in conservation such as translocations, training to avoid predators, and the preservation of animal cultures (Blumstein \& Fernández-Juricic 2004; Buchholz 2007). By understanding how animals behave and react to unusual stimuli, one can better predict how they will react to human-altered environments and conservation products. Understanding how animals have evolved to react to their natural habitats can also inform the development of a psychological (rather than structural) form of biomimesis (design of human-made structures on the basis of biological structures), in which stimuli that elicit appropriate behaviors are incorporated into conservation design. Combining psychological biomimesis with techniques from animal welfare for understanding animals' preferences could result in a powerful conservation design toolbox.

Not all conservation interventions require technical design solutions. Areas that could benefit from collaboration with industrial designers include the improvement of existing conservation products, the adaptation of existing types of products to new sites or species, the integration of small-scale features favored by nonhuman species into human-dominated habitats, and the mitigation of human-animal conflict, where design can be used to influence the behavior or perceptions of humans and nonhuman species. Interdisciplinary collaboration on these projects will encourage conservationists to think explicitly, and communicate clearly, about how they currently use conservation products to achieve ecological goals. We expect this to have several benefits for the development of conservation products. The involvement of a designer or design team in conservation projects will formalize the conservation-product design process, making it explicit and accountable by increasing the probability that it will be documented and available for others to learn from. The accumulation of knowledge about design for wildlife conservation over the course of multiple collaborations will improve the quality of products in general and allow a balance to be developed between universal and local aspects of design for conservation. Eventually, conservation design could become a recognized subdiscipline, like landscape design, and result in the consolidation and diffusion of best practices and innovations.

In addition, collaboration with industrial designers is advantageous due to their training in design. Industrial designers possess the skills to translate a goal (e.g., provide $x$ nest boxes at price $y$ that allow $p$ but prevent q) into a high-quality functional object with greater ease and ingenuity than a person without a design skill set. The process of collaboration should be coordinated so that the conservation problem and the ecological and other goals are first defined by conservation scientists. 
After the problem and goals are defined, the process of collaboration enters a period of iterative adaptation and refinement of design proposals made by industrial designers (Zeisel 2006), ideally followed by a further stage of testing alternative designs.

The potential contribution of designers to conservation is illustrated in a typical example of human-wildlife conflict. A city councilor in Antofagasta, Chile, proposed an artificial nest designed to provide an alternative nesting site for Black Cormorants (Phalacrocorax brasilianus), whose acidic feces damage trees in local parks (Rojas 2008). All previous attempts to remove the cormorant population failed. The artificial cormorant nests consisted of an array of metal baskets on metal posts sunk in the water off the coast. The proposal was not adopted and was criticized for potentially increasing water pollution, ruining the coastal view, and promoting the increase of the cormorant population. In this example a designer could have worked with conservationists to design a nest that would provide a preferred nesting site, hold a desired number of cormorants, provide collection or disposal of feces, and be aesthetically acceptable given its probable visual prominence.

Another interesting possibility is the design of products to replace the use of illegally or unsustainably harvested species. For example, the domestic trade in songbirds in Indonesia is driven primarily by the very popular cultural practice of bird song competitions. Unusual species are caught to act as "master birds," whose role is to provide new song phrases that can be incorporated into the repertoire of species used in competition (e.g., Orange-Headed Ground Thrush (Zoothera citrina) (Jepson 2008). This practice is causing rolling local extinctions of popular bird species (Jepson \& Ladle 2005, 2009). An appropriately designed automated training system could teach captive-bred birds new songs and might be a popular product on the Indonesian market that could lessen the impact of trade on a wide range of song birds. The success of such a venture would be partly determined by the perceived desirability of such an item-a challenge far more suited to industrial designers than conservationists.

\section{Stimulating Collaborations}

Designers consider their field interdisciplinary (Margolin \& Buchanan 1998), and they have a history of collaborating with researchers of human behavior (Zeisel 2006). The environment-behavior-neuroscience paradigm in design and architecture specializes in collaborations between researchers of human behavior and the design of human environments (Zeisel 2006). In this paradigm, structured observations of existing environments, guided by behavioral hypotheses, are integrated to create a final design that can be evaluated during use. An increasing sensitivity to environmental issues among designers could mean an increased interest in using their skills to contribute to conservation. The theoretical discussions of products as mediators of emotions, actors in narratives, and nodes in ecologies of objects and services (i.e., products as feeling and behaving social entities) suggests that direct theoretical comparisons between animal behavior and psychology and the design of products could be well received (Root-Bernstein 2006).

Nevertheless, difficulties are likely to arise in collaborations between conservationists or animal behavior scientists and industrial designers. Landscape designers working with conservationists to design wildlife corridors are reported to be likely to give more weight to aesthetic and intuitive considerations and are also trained to present data less quantitatively than conservation scientists (Makhzoumi \& Pungetti 1999). Conservation values among designers may also sometimes be at odds with developing conservation design. Results of a study of industrial design students in Chile suggest that design students associate conservation with separation of wildlife from humanity. The students who most supported conservation reported the least interest in conservation design, although overall interest was high (Root-Bernstein 2008). Such attitudes are likely to vary across cultures and may depend on environmental education.

A potential way to address some challenges of interdisciplinary collaboration is to develop educational programs that familiarize designers with conservation goals and methods. Design schools may be interested in giving their students the opportunity to develop prototypes or models of products for unusual clients, and they may be willing to offer to host workshops for students on design of products for conservation. Such projects would provide an opportunity to develop interactions and a common vocabulary between conservationists and young and established designers. We also suggest that conservation organizations could set up contests with small awards or small grants for the development of designs of products for conservation. Involving designers in large conservation projects is the ultimate goal for integrating industrial design and conservation.

\section{Conclusions}

Four key benefits could arise from collaborations between designers and conservationists. First, the quality and value of products would be improved. Industrial designers possess skills and experience relevant to increasing the durability of products, the efficiency of production, and related issues that could reduce short- or long-term costs of products. Some industrial designers are also specialists in green design and could help design conservation products that, for example, use recycled or biodegradable materials or are powered by a renewable source of energy. Designers could also design products specific to where and how often they will be used and to 
who (e.g., school children, adult volunteers, or scientists) will assemble, handle, or use them.

Second, innovation and improvement of product function would be improved. Conservation scientists who hope to translate their data into practice generally lack training in the transformation of research results into functional objects. A given result (e.g., a finding such as small mammals prefer narrow, covered corridors, whereas large mammals prefer broad, open corridors) is presented to the designer as a problem (e.g., What kind of corridor design provides narrow, covered crossings and wide, open crossings?), and the designer then produces several possible designs that work within the constraints set by stakeholders, such as number and placement of corridors and costs of construction and maintenance. Design can also be a powerful tool for mitigating animal-wildlife conflicts. Iterative collaboration between researchers (representing the species targeted for conservation), stakeholders, and designers will bring to light further problems and constraints, yielding further suggested solutions until all collaborators are satisfied with the design (Zeisel 2006). Explicit testing of proposed solutions is ideal, but may not always be possible. The inclusion of designers in this process should make explicit the relationship between data, conservation goals, and how those goals will be achieved. Collaboration with designers should also increase the likelihood of innovation and increase the set of possible solutions and thus the probability of finding an effective or optimal solution.

Third, designers may be better positioned to harmonize conservation products with local values. Products for conservation in situ might be preferred by stakeholders if they do not clash with local values regarding, for example, the way the landscape should look (e.g., Burton et al. 2008). Designers have experience with communicating values through design and accommodating design to values. Design of conservation products could also be used as an opportunity to advertise or represent values associated with conservation.

Finally, collaborations may promote the development of psychological biomimesis. We see the development of this approach to design as having potential benefits for conservation and for industrial design of products for the regular commercial market. Conservation will benefit from formalizing and expanding the consideration of animal behavior and psychology in the design of products. Industrial design can also anticipate a new source of ideas and innovations by applying psychological biomimesis to products designed for humans. Although design and architecture students may study some anthropology, they rarely study animal behavior or psychology. Exposure to this field has potential to stimulate design (Root-Bernstein 2006).

There is a clear lack of testing, accountability, and knowledge sharing in the design of most in situ and ex situ conservation products. Evidence from applied research in animal welfare for laboratory and farm animals shows that research on animal behavior and preferences can lead to improvements in design of products used by animals. We suggest that collaboration with industrial designers will improve the process of translating data from conservation research into product solutions. The combination of the research and design processes can develop and identify designs that take into account animals' behavioral and perceptual capacities, conservation goals, and stakeholders' goals, physical and monetary constraints and values. Another, complementary, approach is to target environmental education at industrial designers. Additionally, we strongly recommend publication in conservation or design journals of the development and testing of ex situ and in situ conservation products so that experience can be shared widely and the psychological biomimesis approach to design for animals can be advanced.

Rosenzweig (2003) argues that a significant amount of biodiversity loss can averted by "redesigning anthropogenic habitats so that their use is compatible with use by a broad array of other species." The architects of this "reconciliation ecology" need to blend human needs, desires, and preferences with those of the wildlife that conservation seeks to protect. If this is to be done effectively, conservation needs to engage with design professionals who have the skills to bridge this divide.

\section{Literature Cited}

Barnett, S. W., editor. 2007. Manual of animal technology. Blackwell Publishing, Oxford, United Kingdom.

Baskinger, M. 2007. Autonomy +the aging population: designing empowerment into home appliances. Pages 133-146 in L. Feijs, S. Kyffin, and B. Young, editors. Design and semantics of form and movement: DeSForM 2007. Koninklijke Philips Electronics, Eindhoven, The Netherlands.

Bertram, C. R., and D.-P Moltu. 1986. Reintroducing red squirrels into Regent's Park. Mammal Review 16:82-86.

Blumstein, D. T., and E. Fernández-Juricic. 2004. The emergence of conservation behavior. Conservation Biology 18:1175-1177.

Bolger, D. T., T. A. Scott, and J. T. Rotenberry. 2001. Use of corridor-like landscape structures by bird and small mammal species. Biological Conservation 102:213-224.

Bolton, M., R. Medeiros, B. Hothersall, and A. Campos. 2004. The use of artificial breeding chambers as a conservation measure for cavitynesting procellariiform seabirds: a case study of the Madeiran storm petrel (Oceanodroma castro). Biological Conservation 116:73-80.

Breitenmoser, U., C. Angst, J.-M. Landry, C. Breitenmoser-Wuersten, J. D. C. Linnell, and J.-M. Weber, 2005. Non-lethal techniques for reducing depredation. Pages 49-71 in R. Woodroffe, S. Thirgood, and A. Rabinowitz, editors. People and wildlife: conflict or coexistence? Cambridge University Press, Cambridge, United Kingdom.

Brosius, J. P. 2006. Common ground between anthropology and conservation biology. Conservation Biology 20:683-685.

Buchholz, R. 2007. Behavioral biology: An effective and relevant conservation tool. Trends in Ecology \& Evolution 22:401-406.

Burton, R. J. F., C. Kuczera, and G. Schwartz. 2008. Exploring farmers's cultural resistance to voluntary agri-environmental schemes. Sociologia Ruralis 48:16-37.

Cabezas, S., and S. Moreno. 2006. An experimental study of translocation success and habitat improvement in wild rabbits. Animal Conservation 10:340-348. 
Chan, K. M. A. 2008. Conservation: in a rut, we need rut-inspired solutions. Nature 451:127.

Chetkiewicz, C.-L. B., C. C. St. Clair, and M. S. Boyce. 2006. Corridors for conservation: integrating pattern and process. Annual Review of Ecology, Evolution and Systematics 37:317-342.

Davies, Z. G., and A. S. Pullin. 2007. Are hedgerows effective corridors between fragments of woodland habitat? An evidence-based approach. Landscape Ecology 22:333-351.

Dawkins, M. S. 2006. A user's guide to animal welfare. Trends in Ecology \& Evolution 21:77-82.

Day, T. D., and R. J. MacGibbon. 2002. Escape behavior and physical abilities of vertebrate pests towards electrified and non-electrified fences. Internal report. Xcluder Pest Proof Fencing, Rotorua, New Zealand.

Fiell, C., and P. Fiell. 2003. Designing the 21st century. Taschen, Koln, Germany.

Fiell, C., and P. Fiell. 2006. Industrial design A-Z. Taschen, London.

Forlizzi, J., C. DiSalvo, and F. Gemperle. 2004. Assistive robotics and an ecology of elders living independently in their homes. HumanComputer Interaction 19:25-59.

Goodman, R. M., F. J. Burton, and A. C. Echternacht. 2005. Habitat use of the endangered iguana Cyclura lewisi in a human-modified landscape on Grand Cayman. Animal Conservation 8:397-405.

Griffin, A. S., D. T. Blumstein, and C. S. Evans. 2000. Review: Training captive-bred or translocated animals to avoid predators. Conservation Biology 14:1317-1326.

Gurnell, J., and H. Pepper. 1993. A critical look at conserving the British red squirrel Sciurus vulgaris. Mammal Review 23:127-137.

Hilty, J. A., W. Z. Lidicker Jr., and A. M. Merenlender. 2006. Corridor ecology: the science and practice of linking landscapes for biodiversity conservation. Island Press, London.

Hodgson, A. J., H. Marsh, S. Delean, and L. Marcus. 2007. Is attempting to change marine mammal behavior a generic solution to the bycatch problem? A dugong case study. Animal Conservation 10:263-273.

Hollis, K. L. 1997. Contemporary research on Pavlovian conditioning: a "new" functional analysis. American Psychologist 52:956-965.

Jensen, M. B., and L. J. Pedersen. 2007. The value assigned to six different rooting materials by growing pigs. Applied Animal Behavior Science 108:31-44.

Jepson, P. 2008. Orange-Headed Thrush Zootbera citrina and the avian x-factor. Birding Asia 9:58-60.

Jepson, P., and R. J. Ladle. 2005. Bird keeping in Indonesia: conservation impacts and the potential for substitution-based conservation responses. Oryx 39:1-8.

Jepson, P., and R. J. Ladle. 2009. Governing bird-keeping in Java and Bali: evidence from a household survey. Oryx 43:364-374.

Karlin, B. E., and R. A. Zeiss. 2006. Environmental and therapeutic issues in psychiatric hospital design: toward best practice. Pyschiatric Services 57:1376-1378.

Katzner, T., S. Robertson, B. Robertson, J. Klucsarits, K. McCarty, and K. L. Bildstein. 2005. Results from a long-term nest-box program for American Kestrels: implications for improved population monitoring and conservation. Journal of Field Ornithology 76:217-226.

King, L. E., I. Douglas-Hamilton, and F. Vollrath. 2007. African elephants run from the sound of disturbed bees. Current Biology 17:R832-R833.

Knaepkens, G., E. Maerten, and M. Eens. 2007. Performance of a pooland-weir fish pass for small bottom-dwelling freshwater fish species in a regulated lowland river. Animal Biology 57:423-432.

Ladle, R. J., and P. Jepson. 2008. Toward a biocultural theory of avoided extinction. Conservation Letters 1:111-118.

Makhzoumi, J., and G. Pungetti. 1999. Ecological landscape design and planning: the Mediterranean context. E \& FN Spon, New York.

Margolin, V., and R. Buchanan, editors. 1998. The idea of design: a Design Issues reader. The MIT Press, Boston.

Markopolous, P., and M. Bekker. 2003. On the assessment of us- ability testing methods for children. Interacting with Computers 15:227-243.

Mata, C., I. Hervás, J. Herranz, F. Suárez, and J. E. Malo. 2008. Are motorway wildlife passages worth building? Vertebrate use of roadcrossing structures on a Spanish motorway. Journal of Environmental Management 88:407-415.

McDonald, W., and C. Cassady St. Clair. 2004. Elements that promote highway crossing structure use by small mammals in Banff National Park. Journal of Applied Ecology 41:82-93.

Nicol, C. J., Brocklebank, S. Mendl, and C. M. Sherwin. 2008. A targeted approach to developing environmental enrichment for two strains of laboratory mice. Applied Animal Behavior Science 110:341-353.

Noss, R. F. 1997. The failure of universities to produce conservation biologists. Conservation Biology 11:1267-1269.

Osborn, F. V., and C. M. Hill. 2005. Techniques to reduce crop loss: Human and technical dimensions in Africa. Pages 72-85 in R. Woodroffe, S. Thirgood, and A. Rabinowitz, editors. People and wildlife: conflict or coexistence? Cambridge University Press, Cambridge, United Kingdom.

Piper, W. H., M. W. Meyer, M. Klich, K. B. Tischler, and A. Dolsen. 2002. Floating platforms increase reproductive success of common loons. Biological Conservation 104:199-203.

Read, J. C., and S. MacFarlane. 2006. Using the fun toolkit and other survey methods to gather opinions in child computer interaction. Pages 81-88 in IDC proceedings. Association for Computing Machinery, New York.

Rojas M., M. 2008. "Hotel" para los patos yecos genera polémica en el norte. El Mercurio, 23 November: C8.

Root-Bernstein, M. 2006. Interaction with the cultural niche is mediated by learning, attention, and decision making. Pages 52-57 in L. Feijs, S. Kyffin, and B. Young, editors. Design and semantics of form and movement: DeSForM 2006. Koninklijke Philips Electronics, Eindhoven, The Netherlands.

Root-Bernstein, M. 2008. Stimulating interdisciplinarity and innovation in design solutions for wildlife conservation. MS thesis. Oxford University, Oxford, United Kingdom.

Rosenzweig, M. L. 2003. Reconciliation ecology and the future of species diversity. Oryx 37:194-205.

Shuttleworth, C. M. 1999. The use of nest boxes by the red squirrel Sciurus vulgaris in a coniferous habitat. Mammal Review 29:61-66.

Stamps, J. A., and R. R. Swaisgood. 2007. Someplace like home: Experience, habitat selection and conservation biology. Applied Animal Behavior Science 102:392-409.

Stewart, T. W. 2007. Measuring animal movements in a natural ecosystem: a mark recapture investigation using stream-dwelling snails. American Biology Teacher 69:e6-e16.

Stewart, J. R., and A. M. Lister. 2001. Cryptic northern refugia and the origins of the modern biota. Trends in Ecology \& Evolution 16:608-613.

Thompson, C. F., and A. J. Neill. 1991. House wrens do not prefer clean nest boxes. Animal Behaviour 42:1022-1024.

Venter, F. J., R. J. Naiman, H. C. Biggs, and D. J. Pienaar. 2008. The evolution of conservation management philosophy: Science, environmental change and social adjustments in Kruger National Park. Ecosystems 11:173-192.

Vera, F. W. M. 2000. Grazing ecology and forest history. CABI Publishing, Oxford, United Kingdom.

Wade, M. R., G. M. Gurr, and S. D. Wratten. 2008. Ecological restoration of farmland: progress and prospects. Philosophical Transactions of the Royal Society B 365:831-847.

Woodroffe, R., S. Thirgood, and A. Rabinowitz, editors. 2005. People and wildlife: conflict or coexistence? Cambridge University Press, Cambridge, United Kingdom.

Zeisel, J. 2006. Inquiry by design: environment/ behavior/neuroscience in architecture, interiors, landscape and planning. W.W. Norton, New York. 